\title{
AREAL AND TEMPORAL VARIATION OF PERGOLATION OF WATER THROUGH A SNOW-PACK
}

\author{
By E. J. Langham \\ (Environment Canada, Ottawa, Ontario $\mathrm{K}_{\mathrm{A}} \mathrm{A} \mathrm{EE}_{7}$, Canada)
}

\begin{abstract}
Snow melt water that is uniformly generated over the upper surface of the snow-pack does not percolate homogeneously through the snow. Consequently, the rate of arrival of melt water at a single collector at the lower surface does not give a true measure of the melt rate. The experiment described here measures the spatial variability of flow rate and the temporal variation of this two-dimensional pattern. Data are collected from an array of 64 sensors under control of a microprocessor. The microprocessor checks the consistency of the data, calculates the flow rate for each sensor and transfers the results to a recorder. These mean flow rates are calculated at regular intervals for the duration of the experiment. In this way the temporal and spatial variations of flow rate may be related to variations in meteorological conditions and the evolution of the structure snow-pack as the melting progresses.
\end{abstract}

\section{DISGUSSION}

S. C. Colbeck: The placing of collectors in a snow-pack may result in their being frozen even if the snow-pack is isothermal. Location of collectors at the ground surface would seem even more risky. When you record a different flow from different collectors how will you be able to separate the variations due to true spatial variations and those which are the result of different amounts of freezing in different collectors?

E. J. LANGHAM: There is some heat generated from the electrical circuits of the order of $\mathrm{I}-2 \mathrm{~W}$ and I do not consider the freezing problem a serious one.

R. List: The collector funnel size of $8 \mathrm{~cm} \times 8 \mathrm{~cm}$ appears rather small as compared to the height of the snow cover. Have you any comments?

LANGHAm: The funnel size that was chosen is compatible with the snow-pack size.

P. M. B. FöHN: I wonder what kind of parallel measurements could be made related to freewater content and water input. I think that the water outflow can be measured with a largesize lysimeter quite accurately. I think the major problems are still those concerned with the flow of water in the pack.

\section{THE SHORT-RANGE FOREGASTING OF DISGHARGE FROM A GLAGIATED REGION AND ITS USE FOR OPTIMIZING THE GRANDE DIXENGE S.A. PUMPING PLANTS}

\author{
By G. DAYER \\ (Grande Dixence S.A., I950 Sion, Valais, Switzerland)
}

Abstract. The economical operation of the Grande Dixence S.A. pumping plants
involves an optimal utilization of the electrical energy for pumping the discharges of five
glacierized basins. For each basin, a short-range forecasting model $(3 \mathrm{~d})$ has been implemented
in order to determine, at any time, the future evolution of the hourly discharge curve. The 